\title{
Chapter 7 \\ Everyday Cosmopolitanism in African Cities: Places of Leisure and Consumption in Antananarivo and Maputo
}

\author{
Catherine Fournet-Guérin
}

\subsection{Introduction: “Everyday Cosmopolitanism” and Africa}

African cities are oftentimes not considered to be fully part of the world, treated instead as if they are "off the map" (Robinson 2002) or underdeveloped peripheries playing no role in cultural globalization (Mbembe and Nuttall 2004). Seen from Europe, their populations are also thought to be uniformly "black," obscuring an important ethnic diversity. But especially since the 1990s, African cities have taken in many foreigners from all over the world, including people from China, India, Brazil, and Arab and European countries, not to mention elsewhere in Africa. The high number of migrants from countries of the Global South is a new phenomenon, and they will be the focus of this chapter, approached from the perspective of urban society as a whole. This is one of the major rapid changes experienced in African urban societies, but thus far it has received much less academic attention than similar issues in Europe and North America (Cohen and Vertovec 2002). Seen from other parts of the world, "Africa" and "cosmopolitan" are too often considered as opposites, and Africa has only recently started to be mentioned in academic literature on cosmopolitanism. In this context, I will analyze the southern African metropolises and capital cities of Maputo (in Mozambique) and Antananarivo (in Madagascar, in the Indian Ocean). ${ }^{1}$

\footnotetext{
${ }^{1}$ The materials used in this chapter were gathered during several field research trips to each of these cities, each lasting several weeks, since 2006 for Antananarivo and 2015 for Maputo. I use qualitative methods based on observation, semi-structured interviews with foreign- and native-born residents, and analysis of the discourse and representations of city residents from foreign backgrounds that are made by the media and in all manner of artistic expression. The cities were chosen with the idea of studying and shedding light on two comparably sized capitals of very poor countries in geographical proximity, the sole metropolitan city of each country but practically unknown internationally.
}

C. Fournet-Guérin $(\bowtie)$

Sorbonne Université, Paris, France

(C) The Author(s) 2021

C. Lejeune et al. (eds.), Migration, Urbanity and Cosmopolitanism in a

Globalized World, IMISCOE Research Series,

https://doi.org/10.1007/978-3-030-67365-9_7 
Although the metropolitan areas of Maputo and Antananarivo have populations of two to three million, they rarely figure in studies of Africa or among cities thought to incarnate modernity and globalization. In the media as in the world of academic research, they are considered to be secondary cities, provincial on the continental scale, despite the fact that they contain numerous foreigners who are either passing through or living there permanently (Fournet-Guérin 2019). Although national statistical data is lacking and often unreliable, researchers agree that the number of non-African people living in Africa in the 2000s adds up to several million (Flahaux and de Haas 2016) and that the figure is rising, a fact highlighted in a 2018 report from CNUCED estimating that there were 5.5 million people living in Africa who were not originally from the continent. To give but one example, estimates of the presence of people from China living in Africa vary from several hundred thousand to over a million.

Since the early 2000s, a body of social science research has applied the notion of cosmopolitanism to the Global South, not only demonstrating that it is possible but that one could legitimately consider the interactions between foreigners and "nationals" in places that are economically, politically, and socially dominated on the global scale - in other words, the Global South (Fouquet 2018) - to be cosmopoli$\tan$. The literature has also developed a broader acceptance of what is termed "vernacular" cosmopolitanism (Diouf 2000) or "working class cosmopolitanism," developed by Werbner (1999) to span the diversity of empirical situations existing in the Global North and South alike.

Moreover, comparisons between cities of the Global North and South are now widespread, leading to a renewal of analytical paradigms of the urban (Edensor and Jayne 2012; Myers 2011; Robinson 2006) and the inclusion of everyday life in many analyses of cities in particular (beginning with Appadurai 1996). Since the early 2000s, a large and flourishing body of work has also developed in another thematic field, that of the little-known cosmopolitan character of African cities (Brachet 2009; Boesen and Marfaing 2007; Malaquais 2005). These two fields have very little overlap, however, or at least in Africa: few studies are devoted to cosmopolitanism from a very local, micro, and everyday perspective, based on the experience of residents and the frequentation of certain places. A few such studies exist, such as Amandine Spire's research on foreigners in Lomé and Accra (2011), Thomas Fouquet's work on nocturnal places and practices (2018), ${ }^{2}$ Ola Söderström's work comparing Hanoi and Ougadougou (2013), and Bunkenborg's work on the daily life of Chinese migrants settled in Maputo (2014). This chapter pursues and further contributes to this line of work that has emerged in recent years (FournetGuérin 2017).

The question is whether or not cosmopolitan interactions develop in everyday settings such as neighborhoods, or even at the micro-level, in places like corner grocery stores or hair salons. I approach the issue through places: their architecture and décor, what makes them lively, and who frequents them (Fourchard et al. 2009).

\footnotetext{
${ }^{2}$ This nocturnal approach is not included here.
} 
This work falls within the field of social geography, which examines how social differences manifest in space, and in the field of the sociology of everyday life (Goffman 1963). The cosmopolitan places visited in this chapter include modest places frequented by the residents of working-class neighborhoods and more socially selective places that are often, but not always, geographically central in the city. The chapter explores the extent to which one can speak of "places of cosmopolitan sociability" in these everyday spaces. ${ }^{3}$ Cosmopolitanism is taken to mean the deliberate search for the foreign character of a place or a group of people by others. The hypothesis is that people frequent places of cosmopolitan sociability and consumption precisely because they present a clear connection with someplace else (a foreign owner, clientele, décor, cuisine, etc.) and that the people involved consider the interactions that occur there, in a peaceful and calm setting of copresence, to be pleasant. Both foreign migrants and nationals living in the city think that such interactions are beneficial to local urbanity. ${ }^{4}$

\subsection{New Places of Cosmopolitan Sociability in African Cities}

The appearances of Maputo and Antananarivo have changed since the early 2000s, especially due to the creation of many places of sociability related to the presence of foreigners (mostly from the Global South) and international influences that local entrepreneurs seized upon in a search for novelty. They are places devoted to leisure and/or consumption that reflect either the local incorporation of foreign models or the presence of new foreign groups in the city. This means allowing two meanings for cosmopolitanism, one based on migrants' own practices and representations in connection with the host society (a consequence of new international circulations and migrations), the other referring to the globalization of models that circulate in the world, be they related to culture, architecture, food, or more general consumption styles (Appadurai 1996; Söderström 2013; Fouquet 2018; Choplin and Pliez 2018).

First of all, some places of consumption and leisure are directly imported from standardized international models and constitute what Jacques Lévy (1997) calls "generic places" (see the chapters by Jan Willem Duyvendak and Melissa LeyCervantes in this volume). These are big chain hotels, restaurants, spas, shopping

\footnotetext{
${ }^{3}$ Not all kinds of place of sociability are studied here - only privately-owned ones relating to consumption and leisure practices.

${ }^{4}$ According to Ulf Hannerz, the classic definition of cosmopolitanism is expressed by positive interactions: "Cosmopolitanism ... includes a stance toward diversity itself, toward the co-existence of cultures in the individual experience. A more genuine cosmopolitanism is first of all an orientation, a willingness to engage with the other. It entails an intellectual and aesthetic openness toward divergent cultural experiences, a search for contrasts rather than uniformity" $(1990,239)$. This is the definition of cosmopolitanism used in the limited scope of this chapter, although I recognize the importance of relations of hostility and indifference between foreigners and natives.
} 
centers - places that are identical in any city of the world. Even if these generic places are less present and numerous than in other African metropoles, there is a Radisson Blu hotel in Maputo and both cities have malls with architecture, layout, and décor identical to others worldwide. Indeed, shopping centers are a new type of place of sociability developed according to foreign models (Houssay-Holzschuch and Teppo 2009). Like other major East African cities, the forms currently in style in Antananarivo and Maputo are borrowed more from South Africa, the Gulf countries, and emergent countries in Asia and Latin America than from Europe or North America. These generic places are expressions of an international circulation of models of urban forms representing an international culture, and it is through local practices and the representations made of such places that they become distinctive in each particular locale.

A second type of place of sociability consists of reconstructed or locally created places of global inspiration. They are places inspired by models that circulate internationally, often within more limited cultural contexts (such as the Arab-Muslim or Chinese worlds), but with local roots that ensure that they are original and nonstandardized. Their particularity lies in how they transform generic models locally, either by foreigners importing foreign models or by nationals tapping into them. These include casinos, billiard halls, Chinese and other trendy restaurants (sometimes in regional or national chains, like La Gastronomie Pizza in Madagascar), and independent hotels and private guestroom rentals. For instance, La Gastronomie Pizza was founded by nationals in Antananarivo in the 2000s and features a "drivein" service (the site is itself accessible by mini-bus) where employees deliver orders in the unpaved parking lot, an attention-grabbing décor (dominated by the color red, neon lights, eye-catching posters) intended to look "Western," and an active Facebook page. Numerous elements that made fast-food chains internationally successful in Europe and North America are borrowed and adapted to the local setting: certainly, the prices are high for most of the population, but they are cheaper than restaurants downtown.

Hotels advertised as "boutique hotels" also illustrate this type of place. They are inspired by international codes while also claiming to be unique and rooted in their cultural environment and local architecture. The owner of the Hotel du Louvre in Antananarivo is a Madagascar-born descendent of a French colonist family, and he described the marketing concept of the boutique hotel as "feeling at home and being able to possess the decorative objects you see there" (interview, July 2011). His reference for the décor of the hotel, opened in 2009, was the Hotel Urban in Madrid, whose website presents it as "a meeting place so different and cosmopolitan." Initially, however, designers of this kind of hotel intended to promote a style that was unique and rooted in its local environment, in stark contrast to international chain hotels. Although each boutique hotel may indeed be unique, the global model presiding over the design of all of them nonetheless leads to repetition the world over. So such hotels, considered unique reflections of a particular city, are subject to uses making them territories of the world economy and revelatory of an international 
urban culture that has emerged and spread worldwide since the late nineteenth century. Moreover, boutique hotels first emerged in North American cities like New York: their spread illustrates how permeable African capitals are to the latest international influences emanating from the most symbolic of Euro-American metropolises. Regardless, in their very design combined with their rootedness in a unique local urban space, boutique hotels are indeed places of local translation and reconfiguration of a globally circulating model, which makes them cosmopolitan.

Lastly, places of cosmopolitan sociability can be neo-colonial places, meaning recently created or re-created based on colonial-era models and presented as such. They are based on the colonial imaginary and play on the nostalgia that they promote through their décor, name, and/or location - often in the colonial center of the city. They may be cinemas, bars, restaurants, old train stations converted into shopping centers, jazz clubs, or sporting clubs hosting a range of festive events. Such sites include the Africa Cinema and the seaside Naval Club in Maputo or the Café de la Gare in Antananarivo, which opened in 2009 and was modeled after the colonial-era Buffet de la Gare, a mythic place for the cultural and economic elite. Its owners use this colonial nostalgia to successfully attract a local and international clientele. Such places are recreated, restored, or even built new by foreign investors and are frequented by a very diverse local and foreign clientele attracted to the temporal exoticism of their appealing colonial setting.

\subsection{Users of Cosmopolitan Places: Diverse and Changing Profiles}

In the first approach, these new places of sociability are frequented by the clientele for which they were designed and to which they appeal directly. In the newest Chinese restaurants of the two capitals, a significant proportion of the customers are people originally from China who have settled there permanently since the late 1990s (Park 2006; Ma Mung 2008; Chichava and Duran 2014). We can thus speak of so-called "ethnic" places, meaning that they are both well-known for a specific foreign group and well identified as such by residents from local backgrounds; that being the case, there is nothing original about them. Many residents of Maputo and Antananarivo could easily indicate places frequented by the Chinese, Indians, and other Africans - usually downtown hotels and restaurants, upscale or more workingclass, serving as everyday meeting places and sites for community sociability. For instance, members of the Guinean diaspora in Maputo use the centrally located Hotel 2001 due to the lack of pleasant public places or associative clubs for this purpose.

In such new places of sociability, one can find businessmen from Mozambique/ Madagascar and foreign countries alongside employees of foreign companies and international organizations on mission for a few weeks as well as tourists and evangelical missionaries from Africa or the Americas (Brazil, the United States). 
The Chinese tend to frequent hotels owned by fellow Chinese, like the New Century in Antananarivo and the Moderna Guest House in Maputo, just as the Congolese and Indians have their own favored addresses. A whole collection of communityspecific addresses can be found on the Internet, especially on social networks in the language of each community.

The most interesting part of studying the phenomenon of new places of sociability is that they are also frequented by people from Madagascar or Mozambique, often to the point of being a majority. It is thus possible to speak of genuine cosmopolitan places since these places created by and for foreigners come to be frequented by nationals as well, which can lead to these groups meeting and conversing.

Places opened by foreigners are highly sought after by Malagasies in Antananarivo. The habit developed among the elites in the colonial era. In the 1990s the phenomenon expanded into new places, a sign of international circulations reactivated by the openness resulting from liberalization and the development of air links to Asia. Mozambique developed similarly, according to the same timeframe. Foreign-run places of sociability, especially Chinese ones, have been adopted immediately in recent years, so Malagasies are a significant share of the clientele of Chinese establishments of all kinds built since 2000 - restaurants, billiard halls, massage parlors, and bars. The downtown Chinese hotel New Century has a vast hall with several billiards tables that are mostly used by Malagasy students, who use it as a spacious, centrally located, and accessible place to meet up and relax while enjoying a leisure activity that is central to student sociability. Residents of Antananarivo also enjoy the newly opened Chinese restaurants, which are popular for festive family events like weddings, birthdays and baptisms. Revealingly, in newly-opened foreign restaurants, the menus are written in the country's dominant European language (French or Portuguese) in addition to Mandarin (for example) and contain photographs of the dishes in order to reach the widest number of people possible. The same is true in Maputo, where Chinese-owned groceries and workingclass neighborhood bars are thronged with Mozambicans coming to have a drink, play and bet on a board or card game, or watch a subscription satellite channel broadcast in the establishment. A little grocery owned by a Chinese couple in Catembe, a leisure neighborhood, has a few slot machines used by neighborhood residents, making it another place of sociability for all.

The mixing of nationals and foreigners can also be observed in generic places, leading to a change in how they are used as clients develop local practices that modify and reconfigure their standardized international dimension. One example found widely in southern African cities is the American fast-food chain KFC: as in other cities, the KFC in Maputo is very popular with native-born Maputo residents as well as with foreigners, all seeking a globally standardized setting and flavor. ${ }^{5}$ This is also true for the uses of spaces of sociability in grand hotels, which are frequented by the business bourgeoisie as well as the upper middle classes who hold

\footnotetext{
${ }^{5} \mathrm{KFC}$ opened its very first restaurant in Antananarivo in November 2019. A study of the clientele has yet to be made.
} 
family celebrations there in a practice of conspicuous consumption. Those frequenting these places of generic sociability thus do so for different reasons, according to their social and geographical background, transforming these places through their practices and prompting encounters between very different people in a shared and peaceful setting. People interviewed in such places (in 2011, 2015, 2017) mention the pleasure of being there in the company of foreigners. These generic places are often characterized as deterritorialized, but they are actually appropriated and reconfigured locally by a very wide range of people who contribute to making them unique through their practices in the space. Starting with the real experience of the place, the people frequenting it, and what they hope to find and do there enriches analysis of places of sociability of any kind (Tuan 1977).

If many of the previously mentioned places are centrally located and frequented by a rather well-off, or even wealthy, clientele, they should not be reduced to this socially elite dimension alone (Hiebert 2002; Werbner 1999). The well-off clientele is a good illustration of the development of a local bourgeoisie, newly emerged since the 2000s, that takes advantage of the opening of international exchange and consumes heavily in the city where it resides, just like many affluent foreigners whose presence in the city is expressed in a lifestyle of ostentatious consumption. ${ }^{6}$ It is readily observable in Maputo and Antananarivo, capitals of countries whose low human development indicators demonstrate an otherwise extremely poor population and considerable social and spatial inequalities, especially between the capital and the rest of the country, but also between city residents themselves.

Beyond that, it should be mentioned that there are other places with more working-class kinds of sociability that are frequented by people of modest means: cheap Chinese restaurants and casinos, bars, neighborhood groceries owned by Chinese or foreign African immigrants (the latter only in Maputo: Fournet-Guérin 2019), churches run by foreign evangelical Christian groups (mainly from Congo, South Africa or Brazil), and supermarkets, which are a walking destination for city residents who cannot afford to treat themselves but who are drawn to the place, its scale, its lights, or the abundance of goods on display. In both cities, Chinese-owned supermarkets mainly selling products imported from China are also frequented by nationals, who are drawn by the novelty and exoticism of the goods as well as the décor, musical ambiance, spaciousness, and low prices. In both Maputo and Antananarivo, there is an observable development of such places of local consumption that also serve as places of sociability predominantly frequented by nationals; foreigners open these varied and modest shops in peripheral and often workingclass neighborhoods, and the shops become fully integrated in everyday neighborhood life.

\footnotetext{
${ }^{6}$ This is a well-known phenomenon that was aptly recounted in Adichie's novel Americanah (2013), set in Lagos.
} 


\subsection{Cosmopolitan Imaginations: Why Are These Places Successful with Nationals?}

In academic literature, generic places are sometimes described as being standardized (see, for example, Cauna 2002 on the Caudan Waterfront in Mauritius) and thus supposedly soulless, devoid of local ties, and with no affective dimension for people frequenting it. Behind these value judgments may hide an intellectual social position essentially decrying places touched by international and commercial capitalism. But to do so is to ignore what the people using them actually think and how they actually experience the place, through their practices and representations.

\subsubsection{Participating in a Desired International Modernity}

Cosmopolitan places combine exogenous models and local practices and representations: developed by foreigners, in many cases for their own use, they are rapidly appropriated by nationals and come to be used by both population types. In that, they incarnate new forms of sociability. It furthermore means, contrary to what is regularly asserted, that city residents frequent and appreciate new generic places of sociability not by default but for what they are - as places incarnating a standardized international modernity. Frequenting these new places allows them to take part in life as it is lived around the world, even though they live at the world's periphery and may be bitter about that, if only for the many restrictions on their ability to travel abroad due to their low incomes relative to international standards and the difficulty for citizens of Mozambique or Madagascar to obtain visas to many countries. ${ }^{7}$ The desire for modernity, standardized consumption, and not feeling like you are on the fringe of the world are all powerful motivations that cannot be denied to residents of African cities. Perhaps deploring such practices in the name of the supposed cultural poverty and standardization of these places is a way for Euro-American observers to stick an obsolete image onto societies of the Global South, out of a desire to restrict them to supposedly "authentic" and "traditional" practices? My position is that residents of African cities have the same rights as other urbanites worldwide to frequent generic places, seek the mundane there and try to imitate others, all practices putting them in line with a universal urban experience (for this phenomenon in other settings, see Roy and Ong 2011; Söderström 2013; Myers 2011).

\footnotetext{
${ }^{7}$ As Thomas Fouquet notes, cosmopolitan practices in Africa are first and foremost those of people who cannot travel, "non-mobile individuals" $(2018,6)$.
} 


\subsubsection{The Quest for a New and Not Exclusively Euro-American Exoticism}

While some places of sociability are sought after because they offer access to globalized practices in a standardized setting, others are in demand for their exotic character, associated with a fantasized imaginary of someplace else. ${ }^{8}$ This can be found in décor, cuisine, a kind of activity, or an image of modernity. This is the case for the newly opened Chinese restaurants of Antananarivo, Maputo, and elsewhere in Africa: you eat a locally unknown cuisine in a colorful and busy décor (for example, a profusion of photographs and/or paintings of stereotypical Chinese landscapes on the walls), greatly appreciated by Africans, and in a bright, modern setting that contrasts with many local restaurants, which often have a dim and dreary ambiance. The attraction is clearly exoticism through novelty, escapism, and the consumption of elsewhere. In this sense, the residents of these cities can be said to develop cosmopolitan imaginaries of new places of sociability, meaning that they are sought out for their foreignness. At La City, Antananarivo's most upscale shopping center opened in the early 2010s, the food court has several restaurants offering foreign cuisines. One of them has a menu presenting certain cuisines as exotic in how they are named, such as "yassa" for Senegalese dishes and "caris" or "dishes with coconut" for Creole and Indian dishes. Until recently, in fact, the only foreign cuisines in the capital of Madagascar were French and Chinese, or rather, Cantonese in the version that spread around the world since the late nineteenth century. At Khana Razana, an upscale Indian-Chinese restaurant in downtown Maputo, the owner - an Indian man from Bombay - speaks English with his customers rather than Portuguese (the local lingua franca). The restaurant is very popular with city elites, Mozambicans of Indian descent, ${ }^{9}$ Chinese, and Europeans. Today it is possible to dine on the cuisines of northern Indian Muslims, northern China, Arab countries, Thailand, Vietnam, and beyond.

This goes to show that African city-dwellers do seek exoticism, according to the same criteria identified in Euro-American consumers. Frequenting places that artificially recreate someplace else in a commercial logic is just as desirable for Africans as it is for Europeans and all city people of the world.

\footnotetext{
${ }^{8}$ In French, "exoticism" was first defined from an ethnocentric point of view, as illustrated by the definition in the Petit Robert dictionary (1984): "that which does not belong to our Occidental civilizations, that which comes from far-off countries." But the "Trésor de la Langue Française Informatisé" (Digital Treasury of the French Language; https://www.cnrtl.fr/definition/exotisme) takes a neutral approach: "that which relates or belongs to a foreign country, generally far-off or little known" - meaning that exoticism is conceivable anywhere in the world. It is this second definition that I use here.

${ }^{9}$ By Malagasies/Mozambicans "of Indian descent" or "with Indian roots" I mean the descendants of late-nineteenth century emigrants from the British Indian empire who settled in Africa and on islands in the western Indian Ocean. Their descendants have formed well-identified communities that are often disliked by nationals of African origin. They are quite visibly present in the city and they play a significant role in the national economy.
} 
The frequentation of African urbanites of such pastiche settings signals both a new and expanded imaginary and the local appropriation and adoption of models in global circulation. La Casbah, a "shisha lounge bar restaurant" in Antananarivo, provides an excellent example of this phenomenon. Opened in a neighborhood on the edge of downtown in the 2010s by a Madagascar-born man with Indian roots, its name and décor draw upon an aesthetic that is simultaneously part Arab cultural world, part global standardization: "shisha," "la casbah," and the Arab-Moorish décor are explicit references to an imagined Arab universe that even makes a nod to French colonialism, while the term "lounge" refers to a kind of comfortable setting more associated with English-speaking countries, but in a very internationalized and deterritorialized form. Nothing in the décor or name connects it to Antananarivo or Africa; it could be located anywhere in the world. The space can be understood as an incarnation of a "feature of modernity" based on renewed Orientalism (Dittgen 2017). Clients appreciate the exotic character of the place, its eclectic décor combining several foreign influences, and the presence of socially and ethnically diverse people, even if their gaze is filtered through folklore. The composite décor and cuisine served there are exactly what they are looking for. J.-L. Amselle (2009) has critically examined the idealization of such hybridized places whose clienteles have no interest in the actual "elsewhere" they evoke, concluding that the fashion for cultural mixing in Euro-American cities is empty artifice. Regardless, this trend is becoming apparent in every city of the world, including cities that are considered dominated in international representations (Ye 2019) that no one wants to protect from marketed exoticism. In Antananarivo as in Paris and Shanghai, some residents love nothing more than going to places of sociability that they see as cosmopolitan for a dose of the Other and cultural mixing. This could certainly be seen and denounced as a cultural variation of the domination of capitalism, but it can also be seen as providing groups that are symbolically dominated on the global scale access to a kind of freedom of consumption and expression of desire for other places (Appadurai 1996).

\subsection{Conclusion}

In recent decades, the residents of the two African cities studied here have developed new imaginaries and a new sense of exoticism looking to the entire world, no longer just Euro-American references. Their consumption practices, frequentation of generic places, and activities have led them to develop a kind of sociability motivated by yearning for a change of scene. Invested with cosmopolitan representations, these places express the diffusion of globalization and the circulation of standardized international ideas and practices, which some consider artificial. Far from being limited to an elite, this movement expressing openness toward others concerns a wide swathe of society, but not the entire population. Cosmopolitanism is thus far from marginal in Africa, as the wide-ranging spaces described in this chapter all embody the globalization of imaginaries and references and serve as eloquent illustrations of contemporary transformations in cosmopolitan practices and spaces. 


\section{References}

Adichie, C. N. (2013). Americanah. New York: Knopf.

Amselle, J.-L. (2009[1990]). Logiques métisses. Anthropologie de l'identité en Afrique et ailleurs. Paris: Payot.

Appadurai, A. (1996). Modernity at large. Minneapolis: University of Minnesota Press.

Boessen, E., \& Marfaing, L. (2007). Les nouveaux urbains dans l'espace Sahara-Sahel. Un cosmopolitisme par le bas. Paris: Karthala.

Brachet, J. (2009). Migrations transsahariennes: vers un désert cosmopolite et morcelé. Bellecombe-en-Bauges: Croquant.

Bunkenborg, M. (2014). All part of the master plan? Ethnographic encounters with the Chinese in Mozambique. In C. Alden \& S. Chichava (Eds.), China and Mozambique: From comrades to capitalists (pp. 50-66). Auckland Park: Jacana Media.

Cauna (de), Alexandra. (2002). Du front de mer aux parcs de Port-Louis (Maurice). Géographie et cultures, 41, 39-56.

Chichava, S., \& Duran, J. (2014). Migrants or sojourners? The Chinese Community in Maputo. In C. Alden \& S. Chichava (Eds.), China and Mozambique: From comrades to capitalists (pp. 188-198). Auckland Park: Jacana Media.

Choplin, A., \& Pliez, O. (2018). La mondialisation des pauvres. Loin de Wall Street et de Davos. Paris: Seuil.

Cohen, R., \& Vertovec, S. (Eds.). (2002). Conceiving cosmopolitanism: Theory, context and practice. Oxford: Oxford University Press.

Diouf, M. (2000). The Mourid trade diaspora and the making of a vernacular cosmopolitanism. Codesria Bulletin, 1, 19-30.

Dittgen, R. (2017). Features of modernity, development and 'orientalism': Reading Johannesburg through its 'Chinese' urban spaces. Journal of Southern African Studies, 43(5), 979-996.

Edensor, T., \& Jayne, M. (Eds.). (2012). Urban theory beyond the west: A world of cities. London: Routledge.

Flahaux, M. L., \& De Haas, H. (2016). African migration: Trends, patterns, drivers. Comparative Migration Studies, 4(1). https://comparativemigrationstudies.springeropen.com/ articles/10.1186/s40878-015-0015-6

Fouquet, T. (2018). Grassroots cosmopolitics: Critical notes on a cosmopolitan Africa. African Identities, 16, 219-230.

Fourchard, L., Goerg, O., \& Gomez-Perez, M. (Eds.). (2009). Lieux de sociabilité urbaine en Afrique. Paris: L'Harmattan.

Fournet-Guérin, C. (2017). L'Afrique cosmopolite. Circulations internationales et sociabilités citadines. Rennes: Presses Universitaires de Rennes.

Fournet-Guerin, C. (2019). Un cosmopolitisme de voisinage dans les quartiers populaires de Maputo (Mozambique). European Journal of International Migrations, 35(3 \& 4), 239-265.

Goffman, E. (1963). Behavior in public places: Notes on the social organization of gatherings. Glencoe: Free Press of Glencoe.

Hannerz, U. (1990). Cosmopolitans and locals in world culture. In M. Featherstone (Ed.), Global culture: Nationalism, globalisation and modernity (pp. 237-251). London: Sage.

Hiebert, D. (2002). Cosmopolitanism at the local level: The development of transnational neighborhoods. In R. Cohen \& S. Vertovec (Eds.), Conceiving cosmopolitanism: Theory, context and practice (pp. 209-224). Oxford: Oxford University Press.

Houssay-Holzschuch, M., \& Teppo, A. (2009). A mall for all? Race and public space in postapartheid Cape Town. Cultural Geographies, 16(3), 351-379.

Lévy, J. (1997). Penser la ville: un impératif sous toutes les latitudes. C.E.M.O.T.I., 24, 27-30.

Ma Mung, E. (2008). The new Chinese migration flows to Africa. Social Science Information, 47, 643. https://doi.org/10.1177/0539018408096452

Malaquais, D. (2005). Villes flux. Imaginaires de l'urbain en Afrique aujourd'hui. Politique africaine, 100, 17-37. 
Mbembe, A., \& Nuttall, S. (2004). Writing the world from an African Metropolis. Public Culture, 16(3), 347-372.

Myers, G. (2011). African cities: Alternative visions of urban theory and practice. New York: Zed.

Park, Y. J. (2006). Sojourners to settlers: Early constructions of Chinese identity in South Africa. African Studies, 65(2), 201-223.

Robinson, J. (2002). Global and world cities: A view from off the map. Journal of Urban and Regional Research, 26(3), 531-554.

Robinson, J. (2006). Ordinary cities: Between modernity and development. London: Routledge.

Roy, A. (2011). In O. Aihwa (Ed.), Worlding cities: Asian experiments and the art of being global. Chichester: Wiley-Blackwell.

Söderström, O. (2013). What traveling urban types do: Postcolonial modernization in two globalizing cities. In O. Söderström et al. (Eds.), Critical mobilities (pp. 29-57). London: Routledge.

Spire, A. (2011). L'étranger et la ville en Afrique de l'Ouest. Lomé au regard d'Accra. Paris: Karthala.

Tuan, Y.-F. (1977). Place and space: The perspective of experience. Minneapolis: University of Minnesota Press.

Werbner, P. (1999). Global pathways: Working-class cosmopolitans and the creation of transnational ethnic worlds. Social Anthropology, 1(7), 17-35.

Ye, J. (2019). Re-orienting geographies of urban diversity and coexistence: Analyzing inclusion and difference in public space. Progress in Human Geography, 43(3), 478-495.

Open Access This chapter is licensed under the terms of the Creative Commons Attribution 4.0 International License (http://creativecommons.org/licenses/by/4.0/), which permits use, sharing, adaptation, distribution and reproduction in any medium or format, as long as you give appropriate credit to the original author(s) and the source, provide a link to the Creative Commons license and indicate if changes were made.

The images or other third party material in this chapter are included in the chapter's Creative Commons license, unless indicated otherwise in a credit line to the material. If material is not included in the chapter's Creative Commons license and your intended use is not permitted by statutory regulation or exceeds the permitted use, you will need to obtain permission directly from the copyright holder.

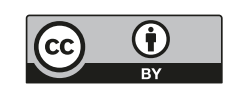

